\title{
Factors Influencing a Firm's Decision to Conduct Remanufacturing: Evidence from the Thai Automotive Parts Industry
}

Jirapan Chaowanapong (as the corresponding author)

School of Management, Asian Institute of Technology,

KM.42, Paholyothin Road, Pathumthani 12120, Thailand

Tel.: +66 896990619

Email: Jirapan.chaowanapong@ait.asia

Dr. Juthathip Jongwanich

Faculty of Economics, Thammasat University

2 Prachan Rd.

Bangkok 10200, Thailand

Tel.: +6626132431

Email: juthathip@econ.tu.ac.th

Dr. Winifred Ijomah

Design Manufacturing and Engineering Management,

Faculty of Engineering

University of Strathclyde

James Weir Building

75 Montrose Street

Glasgow G1 1XJ

Tel: 01415484346

Email: w.1.ijomah@strath.ac.uk

\begin{abstract}
This paper aims to investigate the key factors influencing the decision making process of firms in conducting remanufacturing activities, using the Thai automotive parts as a case study. Our results show that on average, business feasibility is the most influential determinant driving the decision making of firms, followed by areas of the firm's strategic factors, and policy factors. In terms of individual factors, product maturity is ranked first as the most important factor for a firm to engage in remanufacturing activities, followed by financial aspects, availability of skilled workers and technical aspects. Policies related to trade, intellectual property rights and the environment are identified as the least crucial factors in affecting the decision of firms. Characteristics of firms and products matter in ranking the factors influencing a firm's decision to conduct remanufacturing.
\end{abstract}

Keywords Remanufacturing, Automotive part, Thailand, Factor influencing decisionmaking

\section{Introduction}

The rapidly growing awareness of sustainability and environmental issues among consumers, 
industries, and governments is stimulating numerous businesses to adopt environmentallyconscious policies within manufacturing and end-of-life (EOL) strategies (Subramoniam, Huisingh, and Chinnam 2010). The concern for environmental protection has encouraged many new industrial operations to address environmental challenges (Jiang, Zhang, and Sutherland 2011). Remanufacturing represents a potential alternative for gaining environmental and economic advantages by extending product longevity, whilst reducing raw material consumption and energy usage (Lund 1984; Subramoniam et al. 2013).

Remanufacturing engenders comparatively superior quality and reliability compared to other product recovery processes because each product is totally disassembled and its components are restored or replaced to replicate original performance specifications (Guide 2000; Ijomah 2002; Ijomah et al. 2007). The quality of a remanufactured product is guaranteed to be at least as good as that of a newly manufactured product. However, its price tends to be $40 \%$ to $80 \%$ lower than that of an equivalent new product (Steinhilper 2001). Remanufacturing represents a great opportunity to create a win-win situation for all players; the customer receives an attractively priced and quality product, the remanufacturer reduces their manufacturing costs whilst generating profits, and society gains from the lower environmental impact from manufacturing (Östlin 2008; Steinhilper 2001). Remanufacturing is, therefore, considered as a key strategy driving sustainable development (Matsumoto and Ijomah 2013).

The remanufacturing industry embraces a wide range of products. Many empirical studies point out that remanufactured products have spread widely to encompass various industrial sectors, such as automotive parts, medical equipment, cellular phones, computers, photocopiers, single-use cameras, electric home appliances, tires and so on (Ferguson 2009; Matsumoto and Umeda 2011; ÖZER 2012; Rathore, Kota, and Chakrabarti 2011; Sundin 2004). Remanufactured automotive part (RAP) represents the foremost remanufacturing industry, accounting for two-thirds of global remanufacturing operations (USITC 2012). The wide variation of goods within RAP ranges from motor rewinding to engine, for example alternators, starter motors, drive shafts, air conditioning (AC) compressors and gearboxes (Steinhilper 1998).

The implementation of remanufacturing activities has been primarily concentrated in developed countries like the U.S. and the U.K.. Lund and Hauser (2010) recently quantified that in the U.S. more than 6,000 firms are engaged in remanufacturing with over 113 product types. This reflects the readiness of laws and regulations, business strategies, and consumer awareness of remanufactured products in these countries (Rathore, Kota, and Chakrabarti 2011; Xiang and Ming 2011).

However, over the past decade remanufacturing has become an increasingly important activity in developing countries. An involvement with multinational enterprises and liberalization in investment and trade policies has probably helped to stimulate remanufacturing. China, for example, announced regulations concerning RAP and conducted a pilot study in 2008; in addition to identifying remanufacturing as a key component of National Development Planning (Xiang and Ming 2011).

Although the concept of remanufacturing is currently gaining popularity in developing countries, there are only a handful of empirical studies on the factors influencing the strategic decision of firms to conduct remanufacturing activities. In developing countries such remanufacturing research has mostly been conducted in China, India, and Brazil. Yet there is a need for remanufacturing decision-making framework and it is even more necessary for developing countries where remanufacturing is in the initial stage and lacks of remanufacturing knowledge and understanding. This framework could serve as analytic tools 
and techniques to help the firms, particularly small or independent remanufacturers, to decide whether to become involved in remanufacturing and enhance the effectiveness of the remanufacturing activities (Ijomah et al. 2005; Ijomah, Bennett, and Pearce 1999). Furthermore, the seminal work done by Lund (1984) have shown the importance of remanufacturing to developing countries. Recently, Abdulrahman et al. (2015) developed a remanufacturing decision-making framework reflecting the Chinese automotive parts industry using case studies from two firms. Technical concerns are found to be the predominant for implementing remanufacturing whilst regulatory and social issues are less concern. However, neither firm is planning to undertake in-house remanufacturing in the next three years due to a lack of prerequisite technical and managerial capabilities. Wei et al. (2015) examined the motives and barriers for Chinese car part and machinery remanufacturing operations through conducting industrial survey. Environmental and ethical responsibility, customer orientation and strategic advantage are found to be the top three critical motives, whereas customer recognition is the most serious barrier.

Against this backdrop, this paper aims to investigate the key factors influencing the decision making process of firms in developing countries, using the Thai automotive parts sector as a case study. Thailand and automotive parts were chosen for two key reasons. First, Thailand has the potential to be the remanufacturing hub of the Association of South East Asian Nations (ASEAN) because it has been thoroughly integrated into the global production network of leading multinational companies for a long period of time. Its workforce, therefore, has accumulated the necessary manufacturing knowledge and assembly skills, which represent some of the critical success factors for implementing remanufacturing initiatives (Kohpaiboon et al. 2011, 2012). In addition, with the opening of Myanmar and the ASEAN Economic Community (AEC), Thailand has the potential to expand remanufactured goods to ASEAN countries, especially CLMV, i.e. Cambodia, Lao, Myanmar and Vietnam (Kohpaiboon et al. 2012). The Thai government, through the Board of Investment (BOI), is currently attempting to promote remanufacturing activities to support sustainable development.

Second, the automotive sector represents the largest sector within the remanufacturing industry. The automotive part is one of the significant remanufacturing industries in global market, accounting for two-thirds of global remanufacturing operations (USITC 2012). Automotive parts also constitute the key industry conducting remanufacturing activities in Thailand (Kohpaiboon et al. 2011). This would be due to the fact that automotive production is under modular system in which the production process can be divided into many subprocesses and can be outsourced to other firms. Such process generates opportunity for firms in automotive parts to conduct remanufacturing. In addition, reverse logistic costs leading to core acquisition in Thailand are not high since used parts can be easily obtained through various outlets, such as car service centers or independent repair shops, located nationwide. This could help to stimulate remanufacturing in Thailand. While automotive sector in Thailand has been continuously growing, ranked as the $9^{\text {th }}$ and $1^{\text {st }}$ largest automobile producers in the world and in ASEAN respectively in 2013, and there is no regulation in limiting the car useful life, demand for replacement parts continues to grow in the country (OICA 2014; TAI 2012). With its great potential opportunity and the balance of market demand and supply, remanufacturing of automotive parts in Thailand has become an interesting case study. So far there has been no study investigating the factors influencing the decision-making process of firms in this industry conducted in Thailand. Since nature of automotive and automotive parts industry tends to be similar in developing countries, especially modular production system in automotive sector, our findings could, to some extent, shed some light on potential factors influencing remanufacturing activity in automotive parts industry in other developing countries 
The rest of the paper is organized as follows. The second section presents a literature survey with emphasis on the key factors influencing firms' decisions to conduct remanufacturing. The next section outlines the research methodology. The results and discussion are presented in Section 4. Conclusion and policy inferences comprise the final section.

\section{Analytical Framework}

Based on the previous literature, the factors affecting the decision of a firm to conduct remanufacturing ${ }^{1}$ can be grouped into three main areas: business feasibility, firm's strategic factors, and policy factors (Figure 1). Particular factors are highlighted as being key in some studies but not in others. For example, financial feasibility, a component of business feasibility, represents an important factor in Haynsworth and Lyons (1987), Lund (1984), Matsumoto and Umeda (2011), while the organizational aspect, part of a firm's strategic factor, is found to be important only in Abdulrahman et al. (2015), Lund and Skeels (1983), Matsumoto (2010). The details of each factor are discussed below.

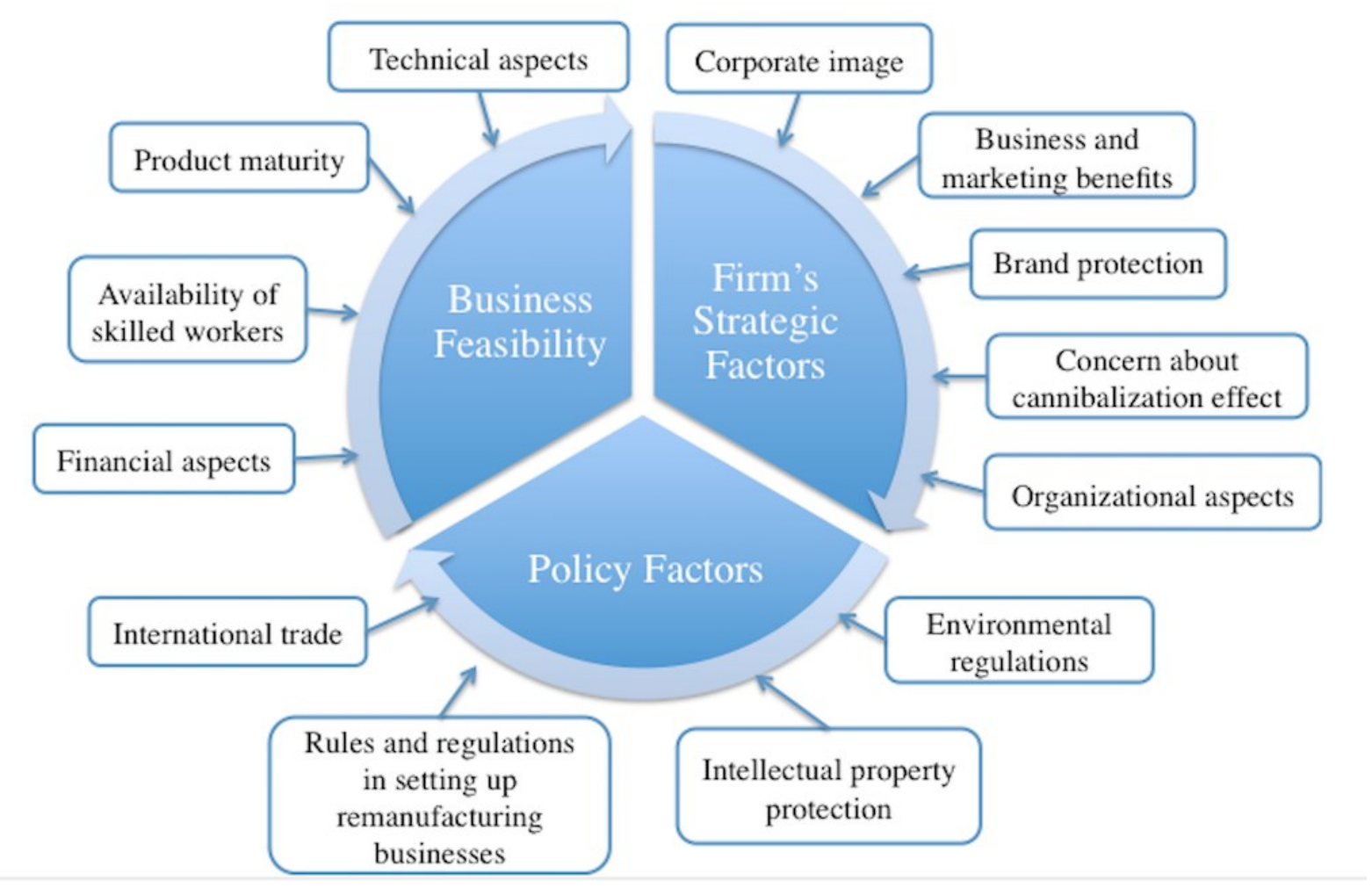

Figure 1 A summary of the factors influencing a firm's decision to conduct remanufacturing

\section{Business Feasibility}

Business feasibility refers to factors that have a direct impact on the profitability of remanufacturing at the firm level. There are five key sub-aspects as follows:

\subsection{Technical Aspects}

\footnotetext{
${ }^{1}$ Remanufacturing definition refers to "the process of returning a used product to at least OEM original performance specification from the customers' perspective and giving the resultant product a warranty that is at least equal to that of a newly manufactured equivalent" (W. Ijomah 2002).
} 
This refers to the ability of products to be disassembled and re-assembled. This is crucial and pre-requisite in determining the business feasibility of remanufacturing. As argued in a number of previous studies (Lund 1984; Bras and Hammond 1996; Hammond, Amezquita, and Bras 1998; Nasr et al. 1998; Subramoniam, Huisingh, and Chinnam 2010), it relates to how products are suitably designed for remanufacturing. The suitable design stage of any product's lifespan affects on reducing production cost, increasing end-of-life possibilities, and leading to profits increases (Hatcher, Ijomah, and Windmill 2011; Sundin, Lindahl, and Ijomah 2009).

In some products, for example, two or more different materials are bonded together. This makes disassembly either costly or impossible so that opportunity for such a product to be remanufactured becomes bleak. Nasr et al. (1998) argued that three-quarters of products are not appropriately designed for disassembly, potentially negatively affecting remanufacturing operations. If this problem still remains, OEMs are unable to maximize their potential to fully remanufacture their products (Hatcher, Ijomah, and Windmill 2011).

Design for remanufacture is the process intended to efficiently disassemble, clean, replace and re-assemble, as well as prolong the life of remanufactured products. This has considerable impacts on remanufacturing efficiency (Zhang et al. 2011; Hatcher, Ijomah, and Windmill 2011; Sundin and Bras 2005). When the products are remanufactured several times, appropriate product design effort and design improvements are even more critical for remanufacturing (Sundin, Lindahl, and Ijomah 2009). To make products more suitable for future remanufacturing, product design for remanufacture must take into consideration in the early stages of production. OEMs play crucial role in this activity since they hold important remanufacturing information i.e. design, production, business models and marketing (Ijomah 2009; Subramoniam, Huisingh, and Chinnam 2009; Subramoniam, Huisingh, and Chinnam 2010; Charter and Gray 2008). However, OEMs cold be either facilitators for product design or be barriers through design strategies to protect their own remanufacturing from independent remanufacturers (IRs) (Charter and Gray 2008).

\subsection{Product Maturity}

Not all products are suitable for remanufacturing depending on product specifications regarding technology and lifespan. As argued in Lund (1984), products with high potential to be remanufactured must exhibit design stability in which the mature product has been on the market for a considerable period without any substantial design changes. This is related to speed of technological innovation change and product lifetimes (Matsumoto 2010). These two specifications determine which EOL product strategies are selected (Umeda, Daimon, and Kondoh 2007). For instance, if a new product incurs rapid technological change, product upgrades are recommended through component replacement, rather than remanufacturing. Likewise, if the physical lifespan of a product is short, the product is unsuitable for remanufacturing (Matsumoto 2010).

\subsection{Availability of Skilled Workers}

A third factor concerns the availability of skilled workers. Lundmark, Sundin, and Björkman (2009) outlined how the process of remanufacturing is complicated and must be implemented by relatively skilled workers. Workers must have better information about products (e.g. product design, parts and their function, etc.) to be able to disassemble, identify parts to be changed, and replace new parts to allow the resumption of original performance. A lack of such expertise potentially represents an obstacle for remanufacturing operations (Abdulrahman et al. 2015). 


\subsection{Financial Aspects}

When remanufacturing is technically feasible, the prospect of business profit plays another crucial role in firms' decisions to implement remanufacturing (Hammond, Amezquita, and Bras 1998; Gillian D Hatcher, Ijomah, and Windmill 2013; Matsumoto 2010; Östlin, Sundin, and Bjorkman 2008; Toffel 2004). Costs and the demand for remanufactured products represent two key factors affecting the prospects of business profitability.

\subsubsection{Cost of Remanufacturing}

The costs of remanufacturing mainly arise from the additional resources needed to ensure products resume their original performance. These include direct production costs (i.e. disassembling, inspection, replacement parts, and re-assembling), the cost of capital equipment, and reverse logistics to obtain cores. Nonetheless, as argued in Subramoniam, Huisingh, and Chinnam (2010), the cost of quality assurance and setting up remanufacturing reverse logistics remain key in determining business profitability.

A lack of control due to the quantity, quality and timing of the cores makes remanufacturing activities more complex and difficult than traditional manufacturing (Lundmark, Sundin, and Björkman 2009; Junior and Filho 2012, 2016). Thus, many studies ${ }^{2}$ on remanufacturing focus on how to set up an effective core management and reverse logistic network as it is regarded as the backbone of remanufacturing operations. When a product is newly launched, limitations of core availability might limit the supply of remanufactured products (Matsumoto 2010). On the contrary when a product has been on the market for a protracted period, it is likely that firms have been able to amass an adequate amount of core to enable them to optimize their remanufacturing operations.

Hence, effective network lower uncertainties in balancing the supply of cores and the demand for remanufactured products (Lundmark, Sundin, and Björkman 2009; Junior and Filho 2012, 2016). The cost saving is largely derived from the fact that remanufacturing companies are able to take advantage of the resources that are used in the original product manufacture. However, how much prices are reduced depends not only on the costs of remanufacturing, but also on the nature of their demand.

\subsubsection{Demand for Remanufactured Goods}

To sustain remanufacturing businesses, sufficient demand for their remanufactured goods is needed. This is especially true for industries where remanufacturing incurs substantial fixed costs. The obvious price differences between remanufactured and new products can cultivate the demand for remanufactured goods due to their lower price with equivalent quality and warrantee to new goods (Amezquita et al. 1995; Lundmark, Sundin, and Björkman 2009). The demand for remanufactured goods may be influenced by consumer perceptions. Potentially, customers have a negative perception towards remanufactured products as they believe the products have inferior quality compared to new products (Abdulrahman et al. 2015; Matsumoto 2010). Such negative perceptions tend to be pronounced in developing countries where knowledge of remanufacturing and environmental awareness is limited. The evidence in Hatcher, Ijomah, and Windmill (2013), based on the experience of OEM suppliers, suggests that managers, designers, or even all staff must

\footnotetext{
2 They include many studies (Lund 1984; Hammond, Amezquita, and Bras 1998; Haynsworth and Lyons 1987; Rahman and Subramanian 2012; Steinhilper 2001; Steinhilper 1998; Subramoniam, Huisingh, and Chinnam 2010; Junior and Filho 2012, 2016; Depuy et al. 2007).
} 
collaborate to place the needs of customers as their first priority.

\section{Firm's Strategic Factors}

These comprise five aspects as follows:

\subsection{Corporate Image}

Amidst growing concerns regarding environmental degradation worldwide and the increasing importance of corporate social responsibility (CSR), many corporates tend to offer environmental-friendly or 'green' products as alternatives to consumers (Subramoniam, Huisingh, and Chinnam 2009, 2010). Wei et al. (2015) found that environmental and ethical responsibility is the most important motives for conducting remanufacturing in China. This helps to improve corporate image. Remanufacturing potentially represents such a green solution as it consumes relatively less resources as opposed to traditional manufacturing. Some materials used in the core are re-used. The experience of Kodak in launching single-use cameras serves as an effective illustration. After the product was launched, the company received negative feedback from customers about "throwaways" and "disposables". This resulted in a boom in remanufactured cameras (Östlin 2008; Östlin, Sundin, and Bjorkman 2008). However, as the literature expounds, the ethical motivation for remanufacturing might not always be substantial. Seitz (2007), for example, found that ethical or moral responsibility had low influence in inducing OEM to conduct remanufacturing in European Vehicle Manufacturer because there is no any eco-friendliness promotion for the benefits of remanufactured products.

\subsection{Business and Marketing Benefits}

Remanufacturing could permit new business strategies for the whole product life cycle, generating new product sales by trading old products (Östlin 2008; Saavedra et al. 2013; Östlin, Sundin, and Bjorkman 2008). This could help the OEM gain more information regarding customer needs, including additional information about after market solutions and product design feedback. In addition, this could assist in securing the supply of spare parts and result in reducing dependency on suppliers, particularly in the case of the part termination (Seitz 2007; Östlin 2008; Östlin, Sundin, and Bjorkman 2008). Specifically for the automotive industry, remanufacturing represents a critical source of replacement engines and may, therefore, be viewed as extending product life.

\subsection{Brand Protection}

Generally, OEMs who have full information on product design, product performance specifications, and material sourcing have at least two options to respond to remanufacturing opportunities. They either undertake remanufacturing operations in-house or outsource them to independent remanufacturers (IRs). Nonetheless, empirical evidence is in favor of the former, i.e. OEMs tend to undertake in-house remanufacturing. This is implemented to protect the product brand of the OEM and lower the risk of inferior quality recovered goods produced by IRs and badged as remanufactured goods (Seitz 2007). In this scenario, OEMs do not share information and try to prevent cores becoming available to IRs (see Seitz (2007) involving the case of automobile engines in Europe and Saavedra et al. (2013) within the context of the Brazilian automotive sector). Although brand protection incentives potentially promote remanufacturing by OEMs, this tends to create difficulty for IRs (Östlin 2008; Saavedra et al. 2013; Östlin, Sundin, and Bjorkman 2008). 
Another factor that could influence a firm's decision to conduct remanufacturing is concerns about cannibalization effects. Offering remanufactured goods might incur negative effects on OEM's new products, which usually generate greater profits than their remanufactured counterparts (Abdulrahman et al. 2015; Linton 2008; Matsumoto 2010). The belief that remanufacturing might stunt the prospect of new products, resulted in the slow progress within the remanufacturing industry found in Brazil (Oiko, Barquet, and Aldo 2011; Saavedra et al. 2013). Nevertheless, the size of any negative effect on new products depends on consumer perceptions towards remanufactured goods compared to new products. In some products, remanufactured and new products fall into different market segments, so that any cannibalization effect would be minimal, (see Östlin, Sundin, and Bjorkman (2008) for a forklift truck-related example).

\subsection{Organizational Aspects}

The ability to create effective management within an organization, especially in terms of integration, alignment and communication between remanufacturing sections and others represents another possible factor determining a firm's decision to conduct remanufacturing. The flexibility of combining manufacturing and remanufacturing operations and strong communication among divisions within a company constitute critical management considerations in achieving remanufacturing success (Lund and Denney 1977; Matsumoto 2010). These help generate effective cost management and productive production planning. Hermansson and Sundin (2005) and Subramoniam, Huisingh, and Chinnam (2010) highlighted not only the importance of organizational aspects by integrating remanufacturing within an original manufacturing but also its service and aftermarket businesses so as to accomplish efficient operations.

\section{Policy Environment}

There are four noteworthy aspects of policy environment as follows:

\subsection{Rules and Regulations in Setting Up Remanufacturing Businesses}

Rules and regulations in setting up remanufacturing businesses, varying from country to country, represent crucial factors influencing remanufacturing activities. Undoubtedly, developed countries like the U.S. and the U.K. are at the forefront in implementing remanufacturing because of their readiness and strict enforcement of specific laws and regulations (Abdulrahman et al. 2015). Hence, setting up remanufacturing businesses in developed countries seems to be easier and more supported than in developing countries. Remanufacturing in India is almost non-existent, and involves only a few firms because of a lack of specific government policies (Mondal and Mukherjee 2006; Rathore, Kota, and Chakrabarti 2011). This evidence is also found in other developing countries, including Brazil (Oiko, Barquet, and Aldo 2011; Saavedra et al. 2013). Governmental legislation restrictions become the serious barriers for undertaking remanufacturing in China (Wei et al. 2015).

\subsection{International Trade}

International trade policy is another influential consideration within remanufacturing. In many countries, remanufactured products are counted as used products. Thus, their importation tends to be subjected to trade barriers. Trade barriers include outright import bans, higher tariffs and fees, or overly-stringent regulations, certification and inspection requirements (US-WTO 2005). For example, Brazil classified cores as used products, and has barriers preventing the import of used products in order to promote local manufacturing. This results in a negative impact on firms establishing remanufacturing businesses when cores are 
not easily available in a local market (Subramoniam, Huisingh, and Chinnam 2009). Malaysia prohibits imports of used automotive parts, including remanufactured goods. Furthermore, India does not allow remanufactured products produced using cores from other countries, allowing only domestic cores.

\subsection{Intellectual Property (IP) Protection}

IP protection could constitute another policy factor influencing firm's decisions to launch remanufacturing businesses (Subramoniam, Huisingh, and Chinnam 2010). IP provides a higher incentive for OEMs to conduct remanufacturing to protect their IP from IRs (Pagell, Wu, and Murthy 2007). In doing so, OEMs hinder IRs in implementing IP systems because they protect cores and prevent product designs disseminating to IRs. Zhang et al. (2011) showed that while USA IP laws permit IRs to remanufacture OEM products, this is not the case in China. Consequently, Chinese IRs tend to be eliminated through IP protection.

\subsection{Environmental Regulations}

Burgeoning environmental concerns have prompted governments in many countries to develop regulations which can constitute significant drivers to the adoption of remanufacturing (Matsumoto 2010; Subramoniam, Huisingh, and Chinnam 2009). Östlin (2008) and Östlin, Sundin, and Björkman (2008) proposed the example of legislation for remanufacturing from the toner cartridge business regulated under the WEEE ${ }^{3}$ Directive, which requires producers to be responsible for post-consumer recycling. To boost remanufacturing in China, Abdulrahman et al. (2015) suggested that the Chinese government should align their regulations to western standards, for examples the guidelines concerning EOL vehicle take-back. Interestingly, Seitz (2007) found that environmental product takeback and recovery legislation is not crucial in promoting remanufacturing activities in European Vehicle Manufacturers because the automotive remanufacturing industry developed long before environmental problems garnered attention as a critical issue.

\section{Methodology}

In order to both fulfill research objectives and reveal valuable insights, this study applied a qualitative approach by conducting interviews, and a quantitative methodology via questionnaires. A case study was conducted through semi-structured interviews and discussions employing open-ended questions with key decision makers representing RAP firms.

As there is currently no registration of remanufacturing firms in Thailand, the estimation of RAP firms comprises approximately 80 firms $^{4}$. Our sample constituted $20 \%$ of overall RAP firms. A purposive sampling strategy was utilized as a tool for informant

\footnotetext{
${ }^{3}$ WEEE DIRECTIVE (2002/96/EC): Waste Electrical and Electronic Equipment requires producers to manage post-consumer recycling and disposal of electronic products effective August 13, 2005.

${ }^{4}$ It is crucial to note that RAP firms in Thailand are defined using the boarder term, which includes both remanufacturing and semi-remanufacturing. The studies of Kohpaiboon et al. $(2011,2012)$ and OIE (2012) proposed the term "semi-remanufacturing" in the Thai case since the products under this category are to some extent similar to the products under rebuilding, reconditioning, and overhauling, but the quality derived from "semi-remanufacturing" seems to be higher. Semi-remanufacturing occurs based on the demand of Thai customers for cheaper product prices. Kohpaiboon et al. $(2011,2012)$ stated that heavily relying on the remanufacturing definition may lead to underestimating the potential and marginal utility of accrued environmental benefits for developing countries, including Thailand. What matters most is resources being reused instead of being sent to be disassembled to become replacement parts, recycled, or dumped in landfill, which generates increased negative impacts on the environment.
} 
selection in order to gain insight into the remanufacturing sector, rather than probability sampling techniques. The significance of purposive sampling lies in identifying informationrich participants with the prerequisite depth and breadth of experience for in-depth analysis (Patton 1990).

The 16 firms were chosen bearing in mind their relevance to this topic and their knowledge and experiences concerning the influencing factors for making decisions to remanufacture, rather than at random (Stuart et al. 2002). Table 1 shows the characteristics of respondents. A wide range of RAP firms, including six engine, four transmissions, two drive shaft, two crane trucks, one AC compressor, and one alternator and starter motor firms were selected to prevent any possible selection bias.

Most firms refer to their remanufacturing activities as "rebuilding"5. The majority of firms comprised IRs and was mostly Thai-owned, with only one OEM being foreign-owned. $70 \%$ of all samples were small-scale firms ${ }^{6}$. In terms of new product sales, $75 \%$ of the firms emphasized their remanufacturing business, while $25 \%$ simultaneously run new product operations. Remanufactured products sold by these firms are three to six times cheaper than new OEM goods. Key informants of each firm interviewed comprise business owners $(70 \%$ of total samples), executive managers $(25 \%)$, and senior officer $(6 \%)$, who have the authority to make decisions concerning remanufacturing activities across 16 selected firms.

Table 1: Conclusion of Characteristics of Respondents

\begin{tabular}{|c|c|c|c|}
\hline \multirow{2}{*}{ Item } & \multirow{2}{*}{ Sub-item } & \multicolumn{2}{|c|}{ Automotive part firm } \\
\hline & & Amount & $\%$ \\
\hline \multicolumn{2}{|c|}{ Automotive part firm (N) } & 16 & $100 \%$ \\
\hline \multirow{6}{*}{$\begin{array}{l}\text { Remanufactured } \\
\text { Product }\end{array}$} & Engine & 6 & $38 \%$ \\
\hline & Drive shaft & 2 & $13 \%$ \\
\hline & Crane truck & 2 & $13 \%$ \\
\hline & Air compressor & 1 & $6 \%$ \\
\hline & $\begin{array}{l}\text { Alternator and } \\
\text { starter motor }\end{array}$ & 1 & $6 \%$ \\
\hline & Transmission & 4 & $25 \%$ \\
\hline \multirow{2}{*}{ Actor } & IR & 15 & $94 \%$ \\
\hline & OEM & 1 & $6 \%$ \\
\hline \multirow{3}{*}{ Firm Size } & Small & 11 & $69 \%$ \\
\hline & Medium & 4 & $25 \%$ \\
\hline & Large & 1 & $6 \%$ \\
\hline \multirow{2}{*}{ Ownership } & Thai-owned & 14 & $88 \%$ \\
\hline & Foreign-owned & 2 & $13 \%$ \\
\hline \multirow{2}{*}{ New Product Sale } & Sale & 4 & $25 \%$ \\
\hline & Not sale & 12 & $75 \%$ \\
\hline \multirow{3}{*}{$\begin{array}{l}\text { Cheaper than new } \\
\text { OEMs }\end{array}$} & 3-4 times & 7 & $44 \%$ \\
\hline & 5-6 times & 3 & $19 \%$ \\
\hline & $\mathrm{N} / \mathrm{A}$ & 6 & $38 \%$ \\
\hline \multirow{2}{*}{$\begin{array}{l}\text { Position of } \\
\text { respondent }\end{array}$} & Owner & 11 & $69 \%$ \\
\hline & Manager & 4 & $25 \%$ \\
\hline
\end{tabular}

\footnotetext{
5 In the automotive industry, there is still debatable about the differences between the terms "rebuilt" and "remanufactured". However, at the bottom line, both terms could be used interchangeably and have the same meaning (APRA 2016).

6 Small-scale enterprise has fewer than 50 employees and medium-scale enterprise has fewer than 200 employees and over of these is large-scale (OSMEP 2015).
} 


\begin{tabular}{|l|l|c|c|}
\hline \multirow{2}{*}{ Item } & \multirow{2}{*}{ Sub-item } & \multicolumn{2}{|c|}{ Automotive part firm } \\
\cline { 3 - 4 } & & Amount & $\%$ \\
\cline { 2 - 4 } & Senior Officer & 1 & $6 \%$ \\
\hline
\end{tabular}

Interviews were conducted during February-June 2014. The length of interviews varied from half an hour to two hours depending on the content and information that firms contributed. Interview and discussion information was supplemented with participatory observations and analysis of company documents. The questions asked when conducting the interview were first tested with a firm owner with over ten years experience of the automotive parts industry and remanufacturing activities. His feedback allowed us to evaluate and then refine the comprehensiveness of the survey instrument.

In order to ensure that the questionnaire was efficiently structured and designed, it was developed in three steps. First, discrete items in the questionnaire were developed based on a thorough literature review. Next, in order to facilitate a review and stimulate suggestions, the questionnaire was sent to six experts involved in the remanufacturing area, including four business owners and two academics. Finally, the questionnaire was developed incorporating their feedback. The respondents replied to a structured questionnaire with indicators on a fivepoint Likert scale (Sekaran 2000). The questionnaire structure was composed of three parts, comprising firm information, influencing factors and personnel information.

After collecting the questionnaires, the data analysis was performed, starting with managing the interview data and field notes from the observations. The audio files which record from all interviews were transcribed and analyzed. After that, the steps of coding and condensing the analyzed data were conducted, and then the codes were combined into categories. The final step was to interpret the results. A Version 22 SPSS statistics program was applied to enable statistical analysis. For calculating the scores of influential levels, descriptive statistical analyses, including mean, standard deviation (S.D.), and median, were performed. The influential levels represent easy indicators, determining the levels of influencing factors. The influential levels, derived from the mean scores, were categorized into five levels: (1) not at all influential $=1.00-1.79$, (2) slightly influential $=1.80-2.59$, (3) somewhat influential $=2.60-3.39,(4)$ very influential $=3.40-4.19$, and (5) extremely influential $=4.20-5.00$.

One-way ANOVA (Analysis of Variance) and t-test were then applied to analyze whether the 13 factors rated differently among remanufactured products (six products), firm size (small, medium and large), ownership (Thai or Foreign), and having remanufacturing with new product sales (yes or no). If the $\mathrm{p}$-value was equal or less than 0.05 , there was seen to be a statistically significant difference.

\section{Results}

The results analyzed from the questionnaires show that all factors identified from the literature review influence respondents' decisions to remanufacture, but additionally to differing degrees depend on firm characteristics, remanufactured product specifications, and Thai context reasons. Figures 2-3 present the results derived from the questionnaires. They were converted from the mean scores 1-5 into five influential levels and then plotted on to graphs. Figure 2 presents the mean scores of 13 influencing factors categorized by the three areas: business feasibility, firm's strategic factors and policy factors. Figure 3 shows the mean scores of the 13 influencing factors. 


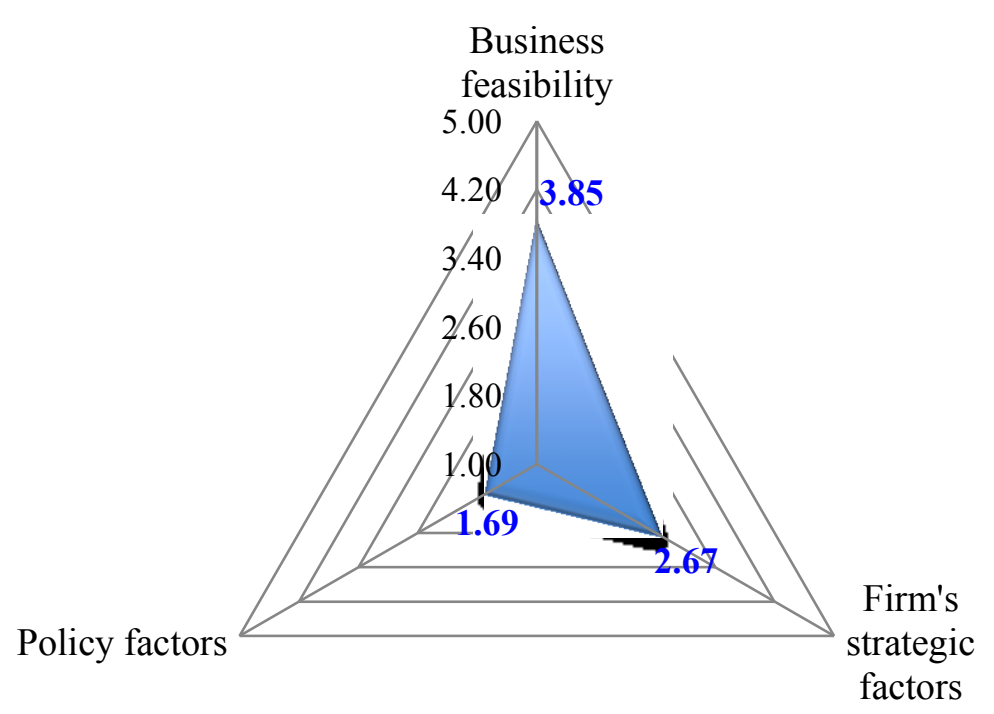

Figure 2 Mean Scores of Three Areas

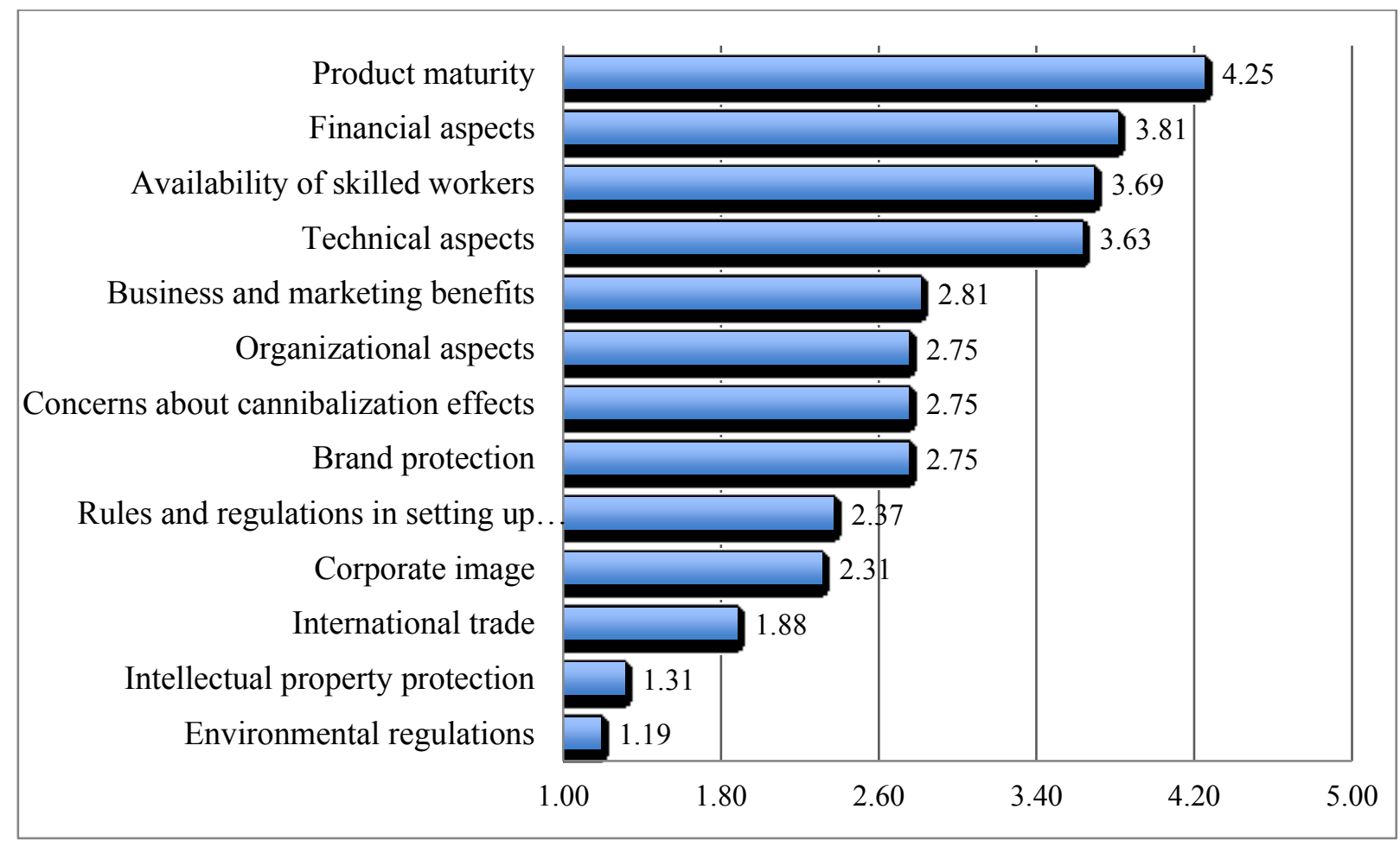

Figure 3 Mean Scores of 13 Influencing Factors

In terms of areas, business feasibility represented the most influential factor, followed by the firm's strategic factors, and policy factors (Figure 3). Within business feasibility, product maturity gained the highest rating score of 4.25 , followed by financial aspects, availability of skilled workers, and technical aspects. For the firm's strategic factors, business and marketing benefit comprises the most important factor in this area, which recorded a rating score of 2.81, while organizational aspects, concerns about cannibalization effects, and brand protection performed equally at 2.75. A detailed analysis of each factor may be seen as follows:

Table 2 T-test and ANOVA Analysis Results 


\begin{tabular}{|c|c|c|c|c|c|c|c|c|}
\hline \multirow{3}{*}{$\begin{array}{l}\text { Variable } \\
\text { Dependent variable }\end{array}$} & \multirow{2}{*}{\multicolumn{2}{|c|}{ Ownership }} & \multirow{2}{*}{\multicolumn{2}{|c|}{ New product sale }} & \multirow{2}{*}{\multicolumn{2}{|c|}{ Firm size }} & & \\
\hline & & & & & & & \multicolumn{2}{|c|}{$\begin{array}{l}\text { Remanufactured } \\
\text { product }\end{array}$} \\
\hline & T-value & P-value & T-value & P-value & F-value & P-value & F-value & P-value \\
\hline Product maturity & -0.642 & 0.531 & 0.000 & 1.000 & 2.382 & 0.131 & 1.871 & 0.187 \\
\hline Technical aspects & 0.354 & 0.782 & -5.698 & $0.000^{*}$ & 0.605 & 0.561 & 1.220 & 0.368 \\
\hline $\begin{array}{l}\text { Availability of skilled } \\
\text { workers }\end{array}$ & 1.668 & 0.117 & -2.507 & $0.025^{*}$ & 0.087 & 0.918 & 1.534 & 0.264 \\
\hline Financial aspects & 0.861 & 0.404 & -1.393 & 0.191 & 0.879 & 0.439 & 0.173 & 0.967 \\
\hline Corporate image & -0.189 & 0.852 & -2.749 & $0.016^{*}$ & 1.139 & 0.35 & 1.252 & 0.355 \\
\hline $\begin{array}{l}\text { Business and marketing } \\
\text { benefits }\end{array}$ & 0.311 & 0.760 & -1.086 & 0.296 & 0.316 & 0.734 & 1.912 & 0.179 \\
\hline Brand protection & -0.247 & 0.809 & -2.175 & $0.047^{*}$ & 1.287 & 0.309 & 0.555 & 0.732 \\
\hline $\begin{array}{l}\text { Concerns about } \\
\text { cannibalization effects }\end{array}$ & 2.073 & 0.119 & 0.000 & 1.000 & 0.120 & 0.888 & 3.596 & $0.040 *$ \\
\hline Organizational aspects & 0.273 & 0.789 & -1.970 & 0.070 & 0.975 & 0.403 & 1.071 & 0.431 \\
\hline $\begin{array}{l}\text { Rules and regulations in } \\
\text { setting up } \\
\text { remanufacturing } \\
\text { businesses }\end{array}$ & 0.347 & 0.734 & 1.205 & 0.256 & 0.244 & 0.787 & 3.267 & 0.052 \\
\hline International trade & -0.145 & 0.887 & -2.358 & $0.033^{*}$ & 0.396 & 0.681 & 1.065 & 0.434 \\
\hline $\begin{array}{l}\text { Intellectual property } \\
\text { protection }\end{array}$ & -0.964 & 0.511 & -0.914 & 0.427 & 127.3 & $0.000^{*}$ & 0.406 & 0.834 \\
\hline $\begin{array}{l}\text { Environmental } \\
\text { regulations }\end{array}$ & 0.508 & 0.619 & -1.567 & 0.215 & 0.397 & 0.680 & 15.750 & $0.000^{*}$ \\
\hline
\end{tabular}

Note: * P-value $\leq 0.05$

Note that each following result for the influential level is regardless of the criteria used (i.e. firm size, ownership, etc.) in Table 2.

\subsection{Business Feasibility}

\subsubsection{Product Maturity}

As an extremely influential consideration; i.e. achieving the top rating score, product maturity was selected by all respondents as a key factor impacting on decisions to remanufacture. The majority of these respondents affirmed that it was worth remanufacturing the product if its remaining lifespan was long enough; i.e. at least $80-100 \%$ that of the new product and still fashionable where the product is fashion affected. Another respondent also stressed that a product was suitable for remanufacturing when technological change impacting on it was slow and it involved low technological complexity. This is in line with the prior literature asserting that products with a high potential to be remanufactured must exhibit a slow speed of technological change to ensure that the lifespan of existing products is long enough to allow firms to conduct remanufacturing (Matsumoto 2010).

\subsubsection{Financial Aspects}

Financial aspects were rated as the second most important factor affecting a firm's decision to conduct remanufacturing. Several respondents from our interview point out that in Thailand the profit margin gained from remanufacturing is higher than trading imported used parts by around $50 \%$. This provides an incentive for firms to conduct remanufacturing. In the context of financial aspects, firms consider both costs (supply) and demand.

Regarding remanufacturing costs, core management is a necessary ingredient for effectively reducing production costs. As indicated by respondents, there are two main avenues of core acquisition. The first source is the domestic market by exchanging return cores for RAP. Firms will sell RAP at the dealing price or at a discount rate that includes 
returned cores from customers. The RAP price depends on the returned core's condition. Firms then incorporate the returned cores into the remanufacturing process. Another source of core accessibility is through import markets, especially from China, Japan, Taiwan and Malaysia.

Several respondents use both paths with their respective ratios depending upon desirable quantity, quality and prices. Many operations import cores as used products for not only remanufacturing, but also for trade as second hand parts within the Sieang-kong group. ${ }^{7}$ Two respondents encountered an issue wherein imported cores were hard to access in sufficient quantities and acceptable quality at reasonable prices. This is compatible with prior literature which addressed the uncertainties in balancing core supply and demand because of a lack of control in quantity, quality and timing (Lundmark, Sundin, and Björkman 2009; Junior and Filho 2012, 2016).

In Thailand, increased labor costs pertaining to the Thai government policy of increasing the minimum wage to 300 baht per day in 2013 from 222-273 baht per day also affects the production cost of remanufacturing. Some firms adjusted their business strategy by reducing the workforce and then attempting to increase labor effectiveness.

A firm's decision to conduct remanufacturing depends also on demand. In Thailand, consumers demand remanufactured products due to their cheaper prices. For example, the price of remanufactured drive shafts is lower than that of new products by at least five to six times, with the same 12 months warranty. If the prices of remanufactured products are not adequately attractive, the customer may select new products imported from China or even used products imported from Japan instead. This is compatible with the uncertainty of customer demand stressed by Lundmark, Sundin, and Björkman (2009) in which remaufacturing acceptance is based on the perceived differences between remanufactured and new products.

To attract more demand, some firms conduct remanufacturing by applying tailormade/customization concepts, which are similar to the "remanufacture-to-order" approach identified in Seitz (2007). This approach is becoming more popular in Thailand as it takes into account customer budget constraints. Customers can select to change only some necessary parts, allowing them to control their budget. For instance, customized remanufactured truck transmissions offered by independent remanufacturers are 1.5 to two times cheaper than general remanufactured ones. Customized transmission is mainly required by maintenance shops or end-users, while remanufactured transmissions are primarily required by large logistics and transportation companies. Some respondents from our interviews expressed that conducting remanufacturing was not prohibitively expensive for their customers. They only require the extension of a products' useful life by installing necessary parts that allow current functionality within their budget limitations. Thailand has many maintenance shops employing skilled technicians and offering affordable prices, the customers can, therefore, frequently change parts.

Although demand for remanufactured products has increased over the past decade, customers' negative perception about the quality of remanufactured products remains a major obstacle for operating remanufacturing. This point is also suggested in the context of Abdulrahman et al. (2015) in China and Matsumoto (2010) in Japan.

\subsubsection{Availability of Skilled Workers}

\footnotetext{
${ }^{7}$ Sieang-kong group refers to the firms gathered by focusing on trading used parts imported from foreign countries mainly from Japan.
} 
Almost all respondents confirmed that the availability of skilled workers are instrumental in maintaining remanufacturing operations. This is because such operations are labor intensive as they involve the complexity of disassembly and reassembly processes. This finding is in line with previous studies (Abdulrahman et al. 2015; Lundmark, Sundin, and Björkman 2009; USITC 2012). For example, when skilled workers merely listen to the noise of an engine destined for remanufacturing, they are able to identify which part needs to be replaced.

Obstacles regarding skilled workers addressed by several interviewees concerned a lack in the requisite quality and quantity. Particularly, workforce of vocational education level tend to lack the technical skills required to get involved in remanufacturing processes. Another hindrance is the high cost of skilled labor pertaining to the Thai government policy that guarantees a minimum wage of 300 baht per day.

For firms selling new products along with remanufactured products, this factor is rated as more critical for operating their business than firms who conduct remanufacturing per se (Table 2). The higher scores of the former could result from the fact that all of the firms who sell new products do so under their own brands. As mentioned above, skilled workers are necessary and even more important for firms producing new products under their own brand auspices.

\subsubsection{Technical Aspects}

Technical aspects were affirmed by respondents as being notably influential in making decisions to remanufacture. They identify the success of running remanufacturing business arising from their specific know-how and expertise, together with an availability of testing tools and machinery. In particular designs for remanufacturing was also confirmed as constituting a critical issue because suitable product design is technically necessary to enable ease of disassembly, cleaning, replacing and reassembling, specifically in the remanufacturing processes.

A respondent stated that if the product has not been properly designed for remanufacture, it would probably decrease production efficiency and increase labor costs. For example, a workforce normally remanufactures alternators or starters motors at a rate of 100 units per week. If the product is difficult to disassemble and reassemble due to its design, the workforce can expedite only 80 units per week. Moreover, several respondents revealed that products that are not designed for disassembly might require specific machinery/tools to complete the process. This will definitely increase a firm's production costs. Regarding this difficulty, respondents argued that it is worth trading in used parts or producing new products, rather than remanufacturing, due to the compararively lower profitability of remanufacturing poorly designed products.

Nevertheless, from our interviews, product design did not represent an obstacle to remanufacturing in cases where OEMs remanufacture their own products. Product design, particularly concerning the difficulty of disassembly and reassembly, is one of the tools OEMs employ to protect IRs from remanufacturing their products. Specific machinery and specialized know-how concerning disassembly and reassembly is required and possessed only by the OEMs themselves. For instance, some brands of drive shafts require specific machinery for their disassembly. Thus, small-scale repair/maintainance shops are unable to remanutacture them. With such specific designs OEMs need to have their own technological advantages. Not surprisingly, our t-test analysis suggests that for firms selling new products 
(one is an OEM and all have their own brands), this factor is rated as more critical for operating their business than firms who conduct only remanufacturing (Table 2).

\subsection{Firm's Strategic Factors}

\subsubsection{Business and Marketing Benefits}

The survey results show business and marketing strategy is somewhat influential in affecting a firm's decision to conduct remanufacturing. Two respondents consider remanufacturing as one of the green marketing strategies required to build their environmentally-friendly image by informing their customers of how remanufactured products generate comparatively less negative impact on the environment. This is compatible with previous studies proposing remanufacturing as a means of promoting a company's green image (Östlin 2008; Östlin, Sundin, and Bjorkman 2008).

Furthermore, remanufacturing represents a strategy for securing spare parts to provide services to customers in order to boost customer satisfaction. One sample firm conducts remanufacturing for a purely service rationale, rather than to increase profitability. Serveral firms necessarily remanufacture only in cases where the part is obsolete due to termination of production. This is in line with the literature review stressing that remanufacturing is an important source of component replacement, particularly concerning automotive parts (Östlin 2008; Seitz 2007; Östlin, Sundin, and Bjorkman 2008).

\subsubsection{Organizational Aspects}

The organizational aspect was considered as being somewhat influential within remanufacturing. Not only organizational flexibility, but also business alignment is necessary to conduct remanufacturing. Moreover, clearly defined roles and job descriptions within an operation are indispensable in properly managing the organization. Routine comunication throughout the organization, for example between divisions like sales and production, for planning optimal production volumes also generate improved organizational alignment. This is in line with previous studies highlighting desirable communication patterns within organization (Lund and Denney 1977; Matsumoto 2010).

However, in Thailand this factor was rated as less influential, compared to the business feasibility aspect. This could be due to the fact that the size of the majority of remanufacturing firms sampled in our research tended to be small and of limited complexity concerning management structure. This factor tends to be more significant in medium and large-sized firms where there exist a hierarchical organizational structure within management. However, our T-test found a statistical insignificance in rating this variable in terms of different firm sizes (Table 2).

\subsubsection{Concerns about Cannibalization Effects}

The respondents identified concerns about cannibalization effects as being at the somewhat influential level. Many firms rate this factor as constituting a moderate concern and point out that there is no conflict between remanufacted and new products since they target different market segments, which is in line with prior studies (Hammond, Amezquita, and Bras 1998; Östlin, Sundin, and Bjorkman 2008). While new parts with first class warranty are needed by car centers, remanufactured products are required more by maintenance shops. Furthermore, some firms have two groups of product with no conflict between them. New products target general customers, whereas remanufactured products 
serve more specific, niche customers who require obsolete parts. Another case involving different market segments concerns firms having two grades of product: grade A for export and $\mathrm{B}$ for domestic markets.

Interestingly, our ANOVA analysis shows that in some remanufactured products, concerns about cannibalization effects are more significant than others (Table 2). For instance, firms producing drive shafts and alternators and starter motors rate this factor higher than those producing of transmissions and crane trucks. This is potentially because the former firms sell both new and remanufactured products under their own brands, while the markets for these products are close substitutes. Therefore, they need to be concerned more about conflict between new and remanufactured products. This issue is irrelevant to transmissions and crane trucks firms as they sell only remanufactured products.

\subsubsection{Brand Protection}

Brand protection was confirmed as only constituting a somewhat influential factor. However, for firms who rate this factor rather highly, it is still important to protect their specific know-how and knowledge. Furthermore, emphasizing product quality helps maintain a firm's reputation, protect their brand and build customer loyalty and confidence. Nevertheless, in Thailand this factor is less crucial since most firms are IRs, focusing less on protecting the brands. By contrast, the majority of literature studies commonly tend to mention OEMs engaging in remanufacturing being keen to protect their brand image or reduce any brand erosion from IRs (Saavedra et al. 2013; Seitz 2007).

Our T-test analysis shows that firms who sell new products along with remanufactured products rate this factor to be significantly more crucial than those who produce only remanufactured products (Table 2). This is probably because all firms who sell both products have their own brand identities, one of which is an OEM. They, thus, are more motivated to protect their brand image by conducting remanufacturing than those who do not have a brand identity to propagate and protect.

\subsubsection{Corporate Image}

Due to a pervading low awareness concerning corporate image, the respondents rated this factor as merely slightly influential. Only one firm focuses on environmental concerns because of the strong green corporate policy encouraged by its headquarters. By contrast, several respondents were concerned about the system of waste disposal in their working area regarding industrial factory regulations, instead of being sincerely concerned about any harmful environmental impact. Firms also stressed that although undertaking remanufacturing could help to preserve raw materials and the environment, its practical, tangible impact is merely as a by-product of their business. Profitability definitely emerges as a more important concern than environmental matters. This factor has little impact on a firm's decision to become involved in remanufacturing since customers choose remanufactured products due to their lower price and replacement part availability, rather than any environment considerations. All in all, any corporate image promotion may be seen as a by-product of engaging in remanufacturing, although it potentially creates the mutual benefit of business profitability and improved environmental care.

This is in line with the study of Seitz (2007) who was unable to confirm ethical and moral responsibility as a motive for automotive engine remanufacturing and Ferrer and Guide (2002) who found that firms still emphasize their main business activities rather than corporate image. This contradicts studies specifically in developed countries confirming that being perceived as environmentally-friendly and exhibiting ethical responsibility are critical considerations for both remanufacturers and their customers (Subramoniam, Huisingh, and 
Chinnam 2009, 2010). While remanufacturing is developed long before the other developing countries, Wei et al. (2015) also found environmental and ethical responsibilities are the motives for remanufacturing in China.

Our T-test analysis shows that this factor is still rated higher for firms who sell new products along with remanufactured products (Table 2). Undoubtedly, firms who sell both products must allocate greater importance to corporate image since they all have their own brand identities through which to present their green credentials and environmental responsibility to their customers. For instance, one OEM who produces both types of goods under their own brand focuses seriously on corporate image owing to following its headquarter's green policy guidelines emanating from Germany.

\subsection{Policy Factors}

\subsubsection{Rules and Regulations in Setting Up Remanufacturing Businesses}

Rules and regulations in setting up remanufacturing businesses were considered as reaching the slightly influential level. Although some respondents see this as being necessary for assisting business establishment, so far in Thailand there are no relevant rules and regulations related directly to setting up this kind of business. They also stressed that even though the government has currently no prohibitory measures targeting remanufacturing businesses, they are not yet promoting or supporting them. There is still no governmental organization in charge of overseeing remanufacturing standards, quality control, and testing systems.

\subsubsection{International Trade}

This factor was also rated at the slightly influential level for affecting the decisions of firms to conduct remanufacturing. The Thai government has identified cores as used goods and has not prohibited the import of used automotive parts, unlike Malaysia and India (USITC 2012). As there is still no governmental prohibition on core imports, some firms perceived this as representing a significant business opportunity to run remanufacturing smoothly. However, several respondents complained that higher tariffs on imported used parts as cores for remanufacturing represent a trade barrier. This causes increased production costs and decreased competitive advantage.

Furthermore, this factor is rated as significant and even more crucial for firms who sell both new and remanufactured products (Table 2). They rely more on international trade because they partly import cores or production ingredients for remanufacturing from foreign countries or some firms export their remanufactured products. This factor is even more critical for one respondent, an OEM, because it is owned by a foreign holding company with intensive international business operations compared to the Thai-owned firms.

\subsubsection{Intellectual Property (IP) Protection}

This factor was rated as slightly influential in impacting the decision of firms to instigate remanufacturing. Overall, IP protection was not found to be particularly noteworthy in this study because most of the sampled firms are IRs, which care less about IPs. Although the fact that know-how accumulated from prolonged experience and technology transfer from previous partners is protected by IP was addressed by some respondents, only few firms identify IP as an influencing factor and also perceive it as worthy of a low score. This is probably because there is a lack of any strict enforcement of IP regulations in Thailand. This is in contrast with the case in developed countries in which IP encourages remanufacturing businesses due to the effective enforcement of regulations (Pagell, Wu, and Murthy 2007). 
Undoubtedly, our ANOVA and interviews show that this factor is significantly more crucial for large-sized firms, of which there is only one representative OEM in this study. This OEM regards this factor as an important incentive because there is a strong IP protection policy stemming from its headquarters in Germany.

\subsubsection{Environmental Regulations}

Identified as not being at all influential, environmental regulations were confirmed as being the least influential factor in the decision to undertake remanufacturing. This result is also found in other studies in emerging countries like China (Abdulrahman et al. 2015; Zhang et al. 2011). The respondents identify that there are no direct environmental regulations regarding remanufacturing operations in Thailand. The relevant regulations are generally standard environmental regulations or industrial factory regulations. They force all manufacturing businesses to mainly be concerned about waste disposal systems in working areas. This is unlike previous research studies 8 in developed countries, where the enforcement of environmental legislation and take-back laws have become major factors driving remanufacturing businesses.

Interestingly, our ANOVA testing and interviews show that this factor is more crucial for some particular remanufactured products, i.e. drive shafts, than others (Table 2). Only drive shaft firms gave environmental regulations a higher score than the other firms. Environmental regulations represent even more critical drivers for drive shaft firms because they emphasize undertaking remanufacturing businesses as a first priority and build their own brands. By contrast, crane trucks and transmission firms, conducting remanufacturing without being under brand banners, which trade used products as a primary business priority, perceive environmental regulations as being the least influential factor impacting their businesses.

\section{Conclusions and Policy Inferences}

This paper aims to investigate the key factors influencing the decision making process of firms in conducting remanufacturing, using the Thai automotive parts sector as a case study. Our results show that on average considering all respondents, business feasibility is the most influential area driving the decision making of firms, followed by areas of a firm's strategic factors, and policy factors. In terms of individual factors, product maturity is ranked first as the most important factor for a firm to engage in remanufacturing activities, followed by financial aspects, which are influenced by both remanufacturing costs and customer demand, availability of skilled labor and technical aspects. Policies related to trade, intellectual property rights and the environment are listed as constituting the least crucial factors affecting the decisions of firms.

Interestingly, the characteristics of firms and products matter in ranking the factors influencing a firm's decision to conduct remanufacturing. Firms who sell both remanufactured and new products tend to place a higher weight on technical aspects; the availability of skilled labor; corporate image; brand protection and policies on trade than firms who process only remanufactured products. IP protection tends to be more crucial in influencing large-sized firm than small and medium-sized operations. Concerns about cannibalization effects and environmental regulations matter more for drive shaft and alternator and starter motor firms, compared to transmission and crane truck firms.

\footnotetext{
8 They include Amezquita et al. (1995), Hammond, Amezquita, and Bras (1998), Östlin 2008; Östlin, Sundin, and Björkman (2008), Subramoniam, Huisingh, and Chinnam (2010), Webster and Mitra (2007), Zuidwijk and Krikke (2008).
} 
From our study, in order to seize opportunities while decreasing obstacles in remanufacturing activities, three areas need to be strengthened. These include laws and regulations related to remanufacturing activities, infrastructure, and human resource development (HRD). The establishment of comprehensive policies and standards is needed in this initial stage of Thai development to stimulate firms to enhance remanufacturing more intensively in order to exploit its potential advantages. End-of-Life vehicles (ELVs) directives, Extended Producer Responsibility (ERP), or even relevant laws and regulations related directly to remanufacturing operations should be established. Regarding infrastructure, the foundation of remanufacturing centers and standards, which hold the key responsibilities of setting up quality control, standards and testing systems, and certification, is required. As soft infrastructure, Research and Development (R\&D) is also needed to improve remanufacturing activities. The strategic directions of HRD should be followed strictly by the requirements of automotive parts firms as key customers. For example, creating and developing practical and up-to-date remanufacturing curricula, particularly in vocational education, represents one path to acheiving successful business ventures.

In terms of contribution to the relevant literature, this paper could potentially stimulate remanufacturing research and development in Thailand, or even other countries where remanufacturing lies also in the infant stages of maturity. Our research could also serve as an effective tool to help decision makers or policy makers, especially in developing countries, to decide whether to become involved in remanufacturing businesses in the automotive part industry, or any other industries, and shed light on ways to properly select the products to be remanufactured.

However, this research was conducted in the context of only one industry, the automotive parts industry sector, in Thailand and limited factors were included. Further case studies and empirical research should be extended to deepen knowledge and generalizability to other products, industries, or countries. Developing research strategies by utilizing comparisons between various industries remain, therefore, the significant challenge facing further research.

\section{Acknowledgements}

The authors would like to gratefully acknowledge the interviewees involved in this study for their valuable contributions, the editor and the anonymous referees for their valuable suggestions and comments. 


\section{References}

Abdulrahman, Muhammad Dan-Asabe, Nachiappan Subramanian, Chang Liu, and Chengqi Shu. 2015. "Viability of Remanufacturing Practice: A Strategic Decision Making Framework for Chinese Auto-Parts Companies." Journal of Cleaner Production 105: 311-323. doi:10.1016/j.jclepro.2014.02.065.

Amezquita, Tony, Rick Hammond, Marc Salazar, and Bert Bras. 1995. "Characterizing the Remanufacturability of Engineering Systems." In Proceedings of ASME Advances in Design Automation Conference, DE-Vol. 82, September 17-20, 271-278.

APRA. 2016. "What Is Remanufacturing?" https://apra.org/?page=Remanufacturing (accessed 14.07.16).

Bras, Bert, and Rick Hammond. 1996. "Towards Design for Remanufacturing - Metrics for Assessing Remanufacturability." In Proceedings of the 1st International Workshop on Reuse, 5-22.

Charter, M, and C Gray. 2008. "Remanufacturing and Product Design." International Journal of Product Development 6 (3-4): 375-392. doi:10.1504/IJPD.2008.020406.

Depuy, G. W., J. S. Usher, R. L. Walker, and G. D. Taylor. 2007. "Production Planning for Remanufactured Products." Production Planning \& Control 18 (7): 573-583. doi:10.1080/09537280701542210.

Ferguson, Mark. 2009. "Strategic Issues in Closed-Loop Supply Chains with Remanufacturing." In Closed-Loop Supply Chains: New Developments to Improve the Sustainability of Business Practices. Auerbach Publications.

Ferrer, G, and V. D. R. Guide. 2002. Remanufacturing Cases and State of the Art. Edited by Robert U. Ayres and Leslie W. Ayres. A Handbook of Industrial Ecology. Cheltenham: Edward Elgar Publishing.

Guide, V. Daniel R. 2000. "Production Planning and Control for Remanufacturing: Industry Practice and Research Needs." Journal of Operations Management 18 (4): 467-483. doi:10.1016/S0272-6963(00)00034-6.

Hammond, R., T. Amezquita, and B. Bras. 1998. "Issues in the Automotive Parts Remanufacturing Industry: Discussion of Results from Surveys Performed among Remanufacturers." International Journal of Engineering Design and Automation Special Issue on Environmentally Conscious Design and Manufacturing 4 (1): 27-46.

Hatcher, G. D., W. L. Ijomah, and J. F C Windmill. 2011. "Design for Remanufacture: A Literature Review and Future Research Needs." Journal of Cleaner Production 19 (1718): 2004-2014. doi:10.1016/j.jclepro.2011.06.019.

Hatcher, Gillian D, Winifred L Ijomah, and James F C Windmill. 2013. "Design for Remanufacturing in China: A Case Study of Electrical and Electronic Equipment." Journal of Remanufacturing 3 (1): 3. doi:10.1186/2210-4690-3-3.

Haynsworth, H C, and Tim Lyons. 1987. "Remanufacturing by Design, the Missing Link." Production and Inventory Management Journal 28 (2): 24-29.

Hermansson, H., and E. Sundin. 2005. "Managing the Remanufacturing Organization for an Optimal Product Life Cycle." In Environmentally Conscious Design and Inverse 
Manufacturing, 146-153. IEEE.

Ijomah, W.L. 2009. “Addressing Decision Making for Remanufacturing Operations and Design-for-Remanufacture.” International Journal of Sustainable Engineering 2 (December): 91-202. doi:10.1080/19397030902953080.

Ijomah, W.L., J.P. Bennett, and J. Pearce. 1999. "Remanufacturing: Evidence of Environmentally Conscious Business Practice in the UK." In Proceedings First International Symposium on Environmentally Conscious Design and Inverse Manufacturing, 192-196.

Ijomah, W.L., S.J. Childe, G.P. Hammond, and C.A. McMahon. 2005. "A Robust Description and Tool for Remanufacturing: A Resource and Energy Recovery Strategy." In The Ecodesign 2005: 4th International Symposium on Environmentally Conscious Design and Inverse Manufacturing, 472-479. doi:10.1109/ECODIM.2005.1619269.

Ijomah, Winifred. 2002. "A Model-Based Definition of the Generic Remanufacturing Business Process." University of Plymouth.

Ijomah, Winifred L., Christopher a. McMahon, Geoffrey P. Hammond, and Stephen T. Newman. 2007. "Development of Design for Remanufacturing Guidelines to Support Sustainable Manufacturing." Robotics and Computer-Integrated Manufacturing 23 (6): 712-719. doi:10.1016/j.rcim.2007.02.017.

Jiang, Zhigang, Hua Zhang, and John W. Sutherland. 2011. "Development of Multi-Criteria Decision Making Model for Remanufacturing Technology Portfolio Selection." Journal of Cleaner Production 19 (17-18): 1939-1945. doi:10.1016/j.jclepro.2011.07.010.

Junior, Muris Lage, and Moacir Godinho Filho. 2012. "Production Planning and Control for Remanufacturing: Literature Review and Analysis." Production Planning \& Control 23 (6): 419-435. doi:10.1080/09537287.2011.561815.

Junior, Muris Lage, and Moacir Godinho Filho. 2016. "Production Planning and Control for Remanufacturing: Exploring Characteristics and Difficulties with Case Studies." Production Planning and Control 27 (3): 212-225. doi:10.1080/09537287.2015.1091954.

Kohpaiboon, A., J. Jongwanich, K. Jhanhorm, A. Tanasritanyakul, K. Rojanakanoksak, K. Wongwat, and W. Suradej. 2012. Study on Strategies of the Preparation and Development of Environmental Products under International Trade Framework (Phase 3). Bangkok: Thammasart University.

Kohpaiboon, A., J. Jongwanich, A. Tanasritanyakul, K. Jhanhorm, and V. Vatinpongphan. 2011. Study on Strategies of the Preparation and Development of Environmental Products under International Trade Framework (Phase 2). Bangkok: Thammasart University.

Linton, Jonathan D. 2008. "Assessing the Economic Rationality of Remanufacturing Products." Journal of Product Innovation Management 25 (3): 287-302. doi:10.1111/j.1540-5885.2008.00301.x.

Lund, R. T. 1984. Remanufacturing: The Experience of the United States and Implications for Developing Countries. Washington, DC. USA: World Bank.

Lund, R. T., and W. M. Denney. 1977. Opportunities and Implications of Extending Product 
Life. Cambridge, MA.: Center for Policy Alternatives, Massachusetts Institute of Technology.

Lund, R. T., and F. Skeels. 1983. Guidelines for an Original Equipment Manufacturer Starting a Remanufacturing Operation. Cambridge, MA: Center for Policy Alternatives, Massachusetts Institute of Technology.

Lund, R T, and W M Hauser. 2010. "Remanufacturing - an American Perspective." In Responsive Manufacturing - Green Manufacturing (ICRM 2010), 5th International Conference on, 1-6. doi:10.1049/cp.2010.0404.

Lundmark, Peter, Erik Sundin, and Mats Björkman. 2009. "Industrial Challenges within the Remanufacturing System." In Swedish Production Symposium, 132-138. Stockholm.

Matsumoto, Mitsutaka. 2010. "Development of a Simulation Model for Reuse Businesses and Case Studies in Japan.” Journal of Cleaner Production 18 (13): 1284-1299. doi:10.1016/j.jclepro.2010.04.008.

Matsumoto, Mitsutaka, and Winifred Ijomah. 2013. "Remanufacturing." In Handbook of Sustainable Engineering, edited by Joanne Kauffman and Kun-Mo Lee, 389-408. Springer Netherlands. doi:10.1007/978-1-4020-8939-8.

Matsumoto, Mitsutaka, and Yasushi Umeda. 2011. "An Analysis of Remanufacturing Practices in Japan.” Journal of Remanufacturing 1 (1): 2. doi:10.1186/2210-4690-1-2.

Mondal, S., and K. Mukherjee. 2006. "An Empirical Investigation on the Feasibility of Remanufacturing Activities in the Indian Economy." International Journal of Business Environment 1 (1): 70-87.

Nasr, N., C. Hughson, E. Varel, and R. Bauer. 1998. State of the Art Assessment of Remanufacturing. Rochester, NY: Rochester Institute of Technology.

OICA. 2014. "Production 2013 Statistics." http://www.oica.net/category/productionstatistics/2013-statistics/ (accessed 01.02.15.).

OIE. 2012. "Remanufacturing Development in Thailand." http://www.oie.go.th/sites/default/files/attachments/km_oie/km_oie_06.pdf.

Oiko, Olivia Toshie, Anna Paula B. Barquet, and Ometto Roberto Aldo. 2011. "Business Issues in Remanufacturing: Two Brazilian Cases in the Automotive Industry." In 18th CIRP International Conference on Life Cycle Engineering, Braunschweig. Proceedings of the 18th CIRP Inter-National Conference on Life Cycle Engineering, 470-475. doi:10.1007/978-3-642-19692-8.

OSMEP. 2015. "Thai Definition of Small and Medium Enterprises." http://www.sme.go.th/Lists/EditorInput/DispF.aspx?List=15dca7fb-bf2e-464e-97e5440321040570\&ID=1781 (accessed 02.05.15.).

Östlin, Johan. 2008. “On Remanufacturing Systems Analysing and Managing Material Flows and Remanufacturing Processes.” Linköping.

Östlin, Johan, Erik Sundin, and Mats Bjorkman. 2008. "Business Drivers for Remanufacturing." In 15th CIRP International Conference on Life Cycle Engineering, 581-586. 
ÖZER, Huriye SABANCI. 2012. "A Review of the Literature on Process Innovation in Remanufacturing." International Review of Management and Marketing 2 (3): 139-155.

Pagell, Mark, Zhaohui Wu, and Nagesh N. Murthy. 2007. "The Supply Chain Implications of Recycling.” Business Horizons 50 (2): 133-143. doi:10.1016/j.bushor.2006.08.007.

Patton, M. Q. 1990. Qualitative Evaluation and Research Methods (2nd Ed.). Newbury Park, CA: Sage.

Rahman, Shams, and Nachiappan Subramanian. 2012. "Factors for Implementing End-of-Life Computer Recycling Operations in Reverse Supply Chains.” International Journal of Production Economics 140 (1): 239-248. doi:10.1016/j.ijpe.2011.07.019.

Rathore, Pragam, Srinivas Kota, and Amaresh Chakrabarti. 2011. "Sustainability through Remanufacturing in India: A Case Study on Mobile Handsets." Journal of Cleaner Production. doi:10.1016/j.jclepro.2011.06.016.

Saavedra, Yovana M.B., Ana P.B. Barquet, Henrique Rozenfeld, Fernando a. Forcellini, and Aldo R. Ometto. 2013. "Remanufacturing in Brazil: Case Studies on the Automotive Sector." Journal of Cleaner Production 53 (August): 267-276. doi:10.1016/j.jclepro.2013.03.038.

Seitz, Margarete a. 2007. "A Critical Assessment of Motives for Product Recovery: The Case of Engine Remanufacturing." Journal of Cleaner Production 15 (11-12): 1147-1157. doi:10.1016/j.jclepro.2006.05.029.

Sekaran, U. 2000. Research Methods for Business: A Skill-Building Approach (3rd Ed). NY: John Wiley \& Sons.

Steinhilper, R. 1998. Remanufacturing: The Ultimate Form of Recycling. Stuttgart: Fraunhofer IRB Verlag.

Steinhilper, R. 2001. "Recent Trends and Benefits of Remanufacturing: From Closed Loop Businesses to Synergetic Networks." In Proceedings Second International Symposium on Environmentally Conscious Design and Inverse Manufacturing, 481-488.

Stuart, I, D McCutcheon, R Handfield, R McLachlin, and D Samson. 2002. "Effective Case Research in Operations Management: A Process Perspective." Journal of Operations Management 20 (5): 419-433. doi:10.1016/S0272-6963(02)00022-0.

Subramoniam, Ramesh, Donald Huisingh, and Ratna Babu Chinnam. 2009.

"Remanufacturing for the Automotive Aftermarket-Strategic Factors: Literature Review and Future Research Needs." Journal of Cleaner Production 17 (13): 1163-1174. doi:10.1016/j.jclepro.2009.03.004.

Subramoniam, Ramesh, Donald Huisingh, and Ratna Babu Chinnam. 2010. "Aftermarket Remanufacturing Strategic Planning Decision-Making Framework: Theory \& Practice." Journal of Cleaner Production 18 (16-17): 1575-1586. doi:10.1016/j.jclepro.2010.07.022.

Subramoniam, Ramesh, Donald Huisingh, Ratna Babu Chinnam, and Suresh Subramoniam. 2013. "Remanufacturing Decision-Making Framework (RDMF): Research Validation Using the Analytical Hierarchical Process." Journal of Cleaner Production 40 (February): 212-220. doi:10.1016/j.jclepro.2011.09.004. 
Sundin, Erik. 2004. "Product and Process Design for Successful Remanufacturing." Linköpings University.

Sundin, Erik, and Bert Bras. 2005. "Making Functional Sales Environmentally and Economically Beneficial through Product Remanufacturing." Journal of Cleaner Production 13 (9): 913-925. doi:10.1016/j.jclepro.2004.04.006.

Sundin, Erik, Mattias Lindahl, and Winifred Ijomah. 2009. "Product Design for Product/service Systems: Design Experiences from Swedish Industry.” Journal of Manufacturing Technology Management 20 (5): 723-753. doi:10.1108/17410380910961073.

TAI. 2012. "Master Plan for Automotive Industry 2012-2016." http://www.thaiauto.or.th/2012/research/research-detail.asp?rsh_id=39 (accessed 18.09.14.).

Toffel, Michael W. 2004. "Strategic Management of Product Recovery." California Management Review 46 (2): 120-141. http://www.people.hbs.edu/mtoffel/publications/Toffel_2004_CMR.pdf.

Umeda, Yasushi, Takayuki Daimon, and Shinsuke Kondoh. 2007. "Life Cycle Option Selection Based on the Difference of Value and Physical Lifetimes." In INTERNATIONAL CONFERENCE ON ENGINEERING DESIGN, ICED'07, 1-12.

US-WTO. 2005. "Negotiating NTBs Related to Remanufacturing and Refurbishing. Communication from the US. Market Access for Non-Agricultural Products." http://www.reman.org/pdf/WTO-reman.pdf (accessed 01.05.15.).

USITC. 2012. "Remanufactured Goods : An Overview of the U.S. and Global Industries, Markets, and Trade." USITC Publication 4356. http://www.usitc.gov/publications/332/pub4356.pdf (accessed 22.08.14.).

Webster, S, and S Mitra. 2007. "Competitive Strategy in Remanufacturing and the Impact of Take-Back Laws." Journal of Operations Management 25 (6): 1123-1140. doi:10.1016/j.jom.2007.01.014.

Wei, Shuoguo, Dongbo Cheng, Erik Sundin, and Ou Tang. 2015. "Motives and Barriers of the Remanufacturing Industry in China." Journal of Cleaner Production 94: 340-351. doi:10.1016/j.jclepro.2015.02.014.

Xiang, Wang, and Chen Ming. 2011. "Implementing Extended Producer Responsibility: Vehicle Remanufacturing in China." Journal of Cleaner Production 19 (6-7): 680-686. doi:10.1016/j.jclepro.2010.11.016.

Zhang, Tongzhu, Jiangwei Chu, Xueping Wang, Xianghai Liu, and Pengfei Cui. 2011. "Development Pattern and Enhancing System of Automotive Components Remanufacturing Industry in China." Resources, Conservation and Recycling 55 (6): 613-622. doi:10.1016/j.resconrec.2010.09.015.

Zuidwijk, Rob, and Harold Krikke. 2008. "Strategic Response to EEE Returns :" European Journal of Operational Research 191 (3): 1206-1222. 